\title{
KAJIAN TUJUH POE ATIKAN PENDIDIKAN PURWAKARTA ISTIMEWA DALAM PERATURAN BUPATI NOMOR 69 TAHUN 2015
}

\author{
Anggy Giri Prawiyogi \\ Universitas Buana Perjuangan \\ anggy.prawiyogi@ubpkarawang.ac.id
}

\section{ABSTRACT}

Purwakarta Regency Government is one of the areas in West Java that continues to focus on restoring local wisdom that lives in its communities. One of them is by promoting the Poe Atikan Istimewa 7 Program Purwakarta Istimewa. The strengthening of his study in the implementation of character education in Purwakarta Regency includes a series of coaching and nurturing activities for students inside and outside the school at the basic education level to develop their own potential, mental, spiritual, noble character, and skills needed for themselves, society, nation and country. Data was obtained from literature studies, documentation, and using a descriptive analysis research approach.

Keywords: Seven Poe Atikan, Character Education, Care in Basic School

\begin{abstract}
ABSTRAK
Pemerintah Kabupaten Purwakarta merupakan salah satu daerah di Jawa Barat yang terus berfokus dalam mengembalikan kearifan lokal yang hidup di masyarakatnya. Salah satunya dengan digalakan Program 7 Poe Atikan Istimewa Purwakarta Istimewa. Penguatan kajiannya dalam penyelenggaraan pendidikan berkarakter di Kabupaten Purwakarta ini meliputi rangkaian kegiatan pembinaan dan pengasuhan pelajar di dalam dan diluar sekolah pada jenjang pendidikan dasar guna mengembangkan potensi diri, mental, spiritual, akhlak mulia, dan keterampilan yang diperlukan bagi dirinya, masyarakat, bangsa dan negaranya. Data diperoleh dari studi literature, dokumentasi, serta menggunakan pendekatan penelitian analisis deskriptif.
\end{abstract}

Kata Kunci: Tujuh Poe Atikan, Pendidikan Karakter, Asuhan di Sekola Dasar

\section{PENDAHULUAN}

Anak merupakan dambaan yang dinantikan setiap orang tua sekaligus anak itu adalah amanah dari Allah kepada setiap orang tua untuk mendidiknya. Pada anak digantungkan harapan akan masa depan suatu bangsa sehingga berbagai cara ditempuh untuk mempersiapkan anak menempuh masa depannya. Menjadi permasalahan ketika anak berkembang tidak sesuai harapan orang tua. Kebanyakan anak berperilaku menggantungkan diri pada orang lain, tidak mempunyai inisiatif untuk menyelasaikan masalah, serta yang dihadapinya atau dengan kata lain anak kurang mandiri (Walgito, 2010). 
Mengharapkan anak berperilaku mandiri dibutuhkan cara untuk membentuk perilaku mandiri. Menurut Walgito (2010) perilaku manusia dipengaruhi oleh lingkungan dan pengaruh dari dalam diri sendiri. Pergaulan dan kemajuan teknologi juga sangat berpengaruh terhadap kurangnya kemandirian anak-anak pada saat ini (Gunarsa, 2008). Dengan demikian perlu adanya tindakan atau perlakuan untuk menumbuhkan kemandirian pada setiap anak supaya tidak selalu menggantungkan dirinya pada orang lain.

Bupati Purwakarta, Kang Dedi Mulyadi, mengeluarkan gagasan untuk para pelajar di Purwakarta dan itu berlaku bagi semua jenjang sekolah. Gagasan tersebut yaitu "Tujuh Hari Pendidikan Istimewa Purwakarta" (Tujub Poé Atikan Pendidikan Purwakarta Istimewa). Dalam tujuh hari belajar tersebut, guru dan siswa memiliki agenda dan tema yang berbeda-beda setiap harinya di dalam kelas, sehingga proses pembelajaran diharapkan lebih bisa diaplikatifkan. Sebagai kaum cendekia, hal tersebut sejalan dengan kepiawaian membaca jaman yang berkembang saat ini. Dalam falsafah orang Sunda ada ungkapan miindung ka waktu, mibapa ka jaman. Caranya dengan mengaplikasikan pendidikan yang didapat di kelas untuk diaplikasikan kembali di masyarakat (Perbup Purwakarta Nomor 69 tahun 2015).

Tujuh poe atikan pendidikan Purwakarta istimewa sangat menarik untuk dikaji secara etnopedagogik, karena di dalam tujuh poe atikan tersebut tersimpan makna dan arti untuk diterapkan kepada siswa sekolah dasar, serta pakaian seragam sekolah yang dikenakan siswa pun beragam setiap harinya yang menjadi ciri dalam tujuh poe atikan ini. Penelitian yang akan dilakukan oleh peneliti difokuskan kepada nilai-nilai karakter yang terkandung di dalam tujuh poe atikan istimewa Purwakarta.

\section{METODE PENELITIAN}

Pendekatan penelitian yang akan digunakan adalah penelitian analisis deskriptif dengan metode pengumpulan data berupa observasi dan wawancara. Adapun lokasi peneitian adalah di SDN 12 Ciseureuh Kabupaten Purwakarta dengan subjek penelitian adalah siswa, guru setempat. Dari hasil observasi dan wawancara di atas, adapun teknik dan instrument pengumpulan data yang digunakan dalam penelitian ini sebagaimana terdaftar dalam tabel berikut (Spradley, 2006):

\begin{tabular}{cccc}
\hline No. & Teknik & Instrumen & Sumber Data \\
\hline 1. & Studi Pustaka & Analisis & Buku, Jurnal \\
\hline
\end{tabular}

Madrosatuna: Jurnal Pendidikan Guru Madrasah Ibtidaiyah 1(1) (2018) 62-72 


\begin{tabular}{|c|c|c|c|}
\hline \multicolumn{4}{|c|}{ (Litrature Pustaka) } \\
\hline 2. & Wawancara & Panduan Wawancara & $\begin{array}{c}\text { Guru dan Siswa } \\
\text { setempat }\end{array}$ \\
\hline 3. & Observasi & $\begin{array}{c}\text { Panduan } \\
\text { Pengamatan }\end{array}$ & $\begin{array}{c}\text { Foto dan Vidio } \\
\text { Kegiatan Tujuh } \\
\text { Poe Atikan } \\
\text { Istimewa } \\
\text { Purwakarta }\end{array}$ \\
\hline
\end{tabular}

\section{HASIL DAN PEMBAHASAN}

Atikan dalam kamus bahasa sunda yaitu didikan. Tujuh poe atikan istimewa Purwakarta yaitu didikan yang diterapkan setiap harinya yang mana setiap harinya mengandung kegiatan dan makna yang berbeda dan penerapan penguatan pendidikan karakter (Perbub Nomor 69 tahun 2015). Adapun isi yang terkandung dalam peraturan Bupati nomor 69 tahun 2015 pasal 5 ayat 1 dan 2 nilai dasar pendidikan berkarakter adalah sebagai berikut:

1. Pendidikan berkarakter diselenggarakan dengan berpedoman kepada nilai kesundaan, 7 (tujub) Poe Atikan Pendidikan Purwakarta Istimewa, atau tujuh (tujuh) Hari Ajaran Pendidikan Purwakarta Istimewa.

2. 7 (tujub) Poe Atikan Pendidikan Purwakarta Istimewa atau 7 (tujuh) Hari Ajaran Pendidikan Purwakarta Istimewa, sebagaimana dimaksud pada ayat (1).

Tujuh poe atikan, memberikan berbagai motivasi kepada siswa, di antaranya adalah tentang keanekaragaman Nusantara, proses hidup dan berkehidupan hingga mengaplikasikan nilai-nilai luhur pendidikan serta nilai karakter kemandirian. Apa yang dilontarkan Bupati Purwakarta, secara filsafat relevan dengan hakikat pendidikan, yaitu sebuah proses panjang dan berkelanjutan untuk mentransformasikan peserta didik menjadi manusia yang sesuai dengan tujuan penciptaannya, bermanfaat bagi dirinya, bagi sesama, bagi alam semesta, beserta segenap isi dan peradabannya. Tujuh hari pendidikan istimewa akan menjadi hal yang bernilai. Karena, nilai berfungsi sebagai penggerak pendidikan. Ia seperti jantung yang memompa darah ke seluruh bagian tubuh. Dengan demikian, tujuan utama pendidikan adalah untuk menghasilkan kepribadian manusia yang matang secara intelektual, emosional, dan spiritual. Karena itulah, komponen esensial manusia adalah nilai (values) dan kebajikan (Perbub Nomor 69 tahun 2015).

Madrosatuna: Jurnal Pendidikan Guru Madrasah Ibtidaiyah 1(1) (2018) 62-72 
Untuk itulah, dalam tujub poe atikan, yang menjadi ruh pendidikan dihidupkan kembali. Menciptakan pendidikan yang penuh dengan nilainilai istimewa tentu saja bukan pekerjaan mudah. Terutama pada zaman sekarang ketika manusia telah dipenjara oleh tujuan-tujuan sekular. Namun, meskipun tidak mudah, nilai istimewa adalah hal esensial yang harus dilakukan dalam pendidikan. Jika tidak dilakukan, maka praktik pendidikan hanya akan menyentuh kulitnya saja dan tidak akan pernah menyentuh ruh yang menjadi jantung pendidikan. Jika ruh pendidikan hilang, anak didik yang dibentuk dalam pendidikan pun akan menjadi manusia yang kehilangan ruh. Akibatnya, kesopanan menjadi tindakan langka, tatakrama menjadi kebiasaan aneh, dan tawuran menjadi kegiatan rutin.

Mengacu kepada fungsi dan tujuan pendidikan nasional, jelas bahwa program tujuh poe atikan di Kabupaten Purwakarta, diselenggarakan secara sistematis yang berkaitan dengan pembentukan karakter peserta didik sehingga mampu bersaing, beretika, bermoral, sopan santun dan berinteraksi dengan masyarakat. Apabila merujuk kepada hasil penelitian di Harvard University Amerika Serikat ternyata kesuksesan seseorang tidak ditentukan semata-mata oleh pengetahuan dan kemampuan teknis (hard skill) saja, tetapi lebih oleh kemampuan mengelola diri dan orang lain (soft skill). Penelitian ini mengungkapkan, kesuksesan hanya ditentukan sekitar 20 persen oleh hard skill dan sisanya 80 persen oleh soft skill. Bahkan orangorang tersukses di dunia bisa berhasil dikarenakan lebih banyak didukung kemampuan soft skill daripada hard skill. Hal ini mengisyaratkan bahwa mutu program tujuh poe atikan peserta didik sangat penting untuk ditingkatkan.

Program tujub poe atikan di Kabupaten Purwakarta merupakan nilainilai perilaku manusia yang berhubungan dengan Tuhan Yang Maha Esa, diri sendiri, sesama manusia, lingkungan, dan kebangsaan yang terwujud dalam pikiran, sikap, perasaan, perkataan, dan perbuatan berdasarkan norma-norma agama, hukum, tata krama, budaya, dan adat istiadat.

Jelasnya, program tujuh poe atikan adalah suatu sistem penanaman nilai-nilai karakter kepada warga sekolah yang meliputi komponen pengetahuan, kesadaran atau kemauan, dan tindakan untuk melaksanakan nilai-nilai tersebut, baik terhadap Tuhan Yang Maha Esa, diri sendiri, sesama, lingkungan, maupun kebangsaan sehingga menjadi manusia insan kamil. Dalam program tujuh poe atikan, semua komponen (stakeholders) terlibat, termasuk komponen-komponen pendidikan itu sendiri, yaitu isi 
kurikulum, proses pembelajaran dan penilaian, kualitas hubungan, penanganan atau pengelolaan mata pelajaran, pengelolaan sekolah, pelaksanaan aktivitas atau kegiatan ko-kurikuler, pemberdayaan sarana prasarana, pembiayaan, dan etos kerja seluruh warga dan lingkungan sekolah.

Terlepas dari berbagai kekurangan dalam praktik pendidikan di Indonesia, apabila dilihat dari standar nasional pendidikan yang menjadi acuan pengembangan kurikulum (KTSP), dan implementasi pembelajaran dan penilaian di sekolah, tujuan pendidikan sebenarnya dapat dicapai dengan baik. Pembinaan karakter juga termasuk dalam materi yang harus diajarkan dan dikuasai serta direalisasikan oleh peserta didik dalam kehidupan sehari-hari. Permasalahannya, program tujub poe atikan di Kabupaten Purwakarta selama ini baru menyentuh pada tingkatan pengenalan norma atau nilai-nilai, dan belum pada tingkatan internalisasi dan tindakan nyata dalam kehidupan sehari-hari.

Menurut UU No 20 Tahun 2003 Tentang Sistem Pendidikan Nasional pada Pasal 13 Ayat 1 menyebutkan bahwa jalur pendidikan terdiri atas pendidikan formal, nonformal, dan informal yang dapat saling melengkapi dan memperkaya. Pendidikan informal adalah jalur pendidikan keluarga dan lingkungan.Pendidikan informal sesungguhnya memiliki peran dan kontribusi yang sangat besar dalam keberhasilan pendidikan. Peserta didik mengikuti pendidikan di sekolah hanya sekitar 7 jam per hari, atau kurang dari 30\%. Selebihnya (70\%), peserta didik berada dalam keluarga dan lingkungan sekitarnya. Jika dilihat dari aspek kuantitas waktu, pendidikan di sekolah berkontribusi hanya sebesar $30 \%$ terhadap hasil pendidikan peserta didik.

Selama ini, pendidikan informal terutama dalam lingkungan keluarga belum memberikan kontribusi berarti dalam mendukung pencapaian kompetensi dan pembentukan karakter peserta didik. Kesibukan dan aktivitas kerja orang tua yang relatif tinggi, kurangnya pemahaman orang tua dalam mendidik anak di lingkungan keluarga, pengaruh pergaulan di lingkungan sekitar, dan pengaruh media elektronik ditengarai bisa berpengaruh negatif terhadap perkembangan dan pencapaian hasil belajar peserta didik. Salah satu alternatif untuk mengatasi permasalahan tersebut adalah melalui program tujub poe atikan, yaitu memadukan dan mengoptimalkan kegiatan pendidikan informal lingkungan keluarga dengan pendidikan formal di sekolah. Dalam hal ini, waktu belajar peserta

Madrosatuna: Jurnal Pendidikan Guru Madrasah Ibtidaiyah 1(1) (2018) 62-72 
didik di sekolah perlu dioptimalkan agar peningkatan mutu hasil belajar dapat dicapai, terutama dalam pembentukan karakter peserta didik.

Program tujub poe atikan di Kabupaten Purwakarta, diintegrasikan dalam pembelajaran pada setiap mata pelajaran. Materi pembelajaran yang berkaitan dengan norma atau nilai-nilai pada setiap mata pelajaran dikembangkan, dieksplisitkan, dikaitkan dengan konteks kehidupan seharihari. Dengan demikian, pembelajaran nilai-nilai karakter tidak hanya pada tataran kognitif, tetapi menyentuh pada internalisasi, dan pengamalan nyata dalam kehidupan peserta didik sehari-hari di lingkungan sekolah.

Program tujuh poe atikan juga, sangat terkait dengan manajemen atau pengelolaan sekolah. Pengelolaan yang dimaksud adalah bagaimana program tujub poe atikan direncanakan, dilaksanakan, dan dikendalikan dalam kegiatan-kegiatan pendidikan di sekolah secara memadai. Pengelolaan tersebut antara lain meliputi, nilai-nilai yang perlu ditanamkan, muatan kurikulum, pembelajaran, penilaian, pendidik dan tenaga kependidikan, dan komponen terkait lainnya. Dengan demikian, manajemen sekolah ini merupakan salah satu media yang efektif dalam program tujuh poe atikan.

Program tujub poe atikan bertujuan untuk meningkatkan mutu penyelenggaraan dan hasil pendidikan di sekolah yang mengarah pada pencapaian pembentukan karakter dan akhlak mulia peserta didik secara utuh, terpadu, dan seimbang, sesuai standar kompetensi lulusan.

Pengembangan program tujub poe atikan di Kabupaten Purwakarta yang dijelaskan oleh Uup Abdul Rauf guru wali kelas VI, bahwa tujuh poe atikan dikembangkan sesuai dengan relevansi di bawah koordinasi dan supervisi Dinas Pendidikan Pemuda dan Olahraga Kabupaten Purwakarta. Pengembangan tujuh poe atikan ini, mengacu pada Standar Isi (SI) dan Standar Kompetensi Lulusan (SKL) dan berpedoman pada panduan penyusunan kurikulum yang disusun oleh BSNP, serta memperhatikan pertimbangan komite sekolah, yang dikembangkan berdasarkan prinsipprinsip sebagai berikut:

\section{Senin (Ajeg Nusantara)}

Dalam Ajeg Nusantara, guru mengajar di kelas menjelaskan tentang aneka ragam Nusantara. Baik keadaan alamnya maupun kebudayaannya. Contohnya mengenakan pakaian pramuka. Guru dan siswa mengenakan pakaian pramuka lengkap. Artinya, sebagai wujud persamaan kenusantaraan yang ksatria, karena pakaian pramuka tidak mengenal

Madrosatuna: Jurnal Pendidikan Guru Madrasah Ibtidaiyah 1(1) (2018) 62-72 
perbedaan warna jenjang sekolah atau pun daerah. Guru semua mata pelajaran menerangkan materi dan bahan ajar dihubungkan dengan semangat kenusantaraan. Contohnya:

a. Guru IPS menerangkan materi ajar kerajaan-kerajaan yang pernah ada di Nusantara beserta keunggulannya.

b. Guru PKn menerangkan ke-bhineka tunggal ika-an.

c. Guru Matematika menghubungkan ilmu hitung dengan luasnya wilayah Nusantara.

d. Guru IPA menerangkan beragam hayati yang ada di Nusantara, dst.

Pada akhir pelajaran sebelum pulang, guru membimbing siswa menyanyikan lagu salah satu lagu wajib nasional yang bertemakan kenusantaraan, contohnya Bagimu Negeri, Dari Sabang Sampai Merauke, dll. Guru memberi pertanyaan kepada siswa seputar Nusantara. Contohnya: "Apa nama selat yang menghubungkan Pulau Jawa dengan Pulau Sumatera? Siswa yang unjuk tangan paling dahulu berhak menjawab, dan jika jawabannya benar maka dia boleh ke luar kelas paling dahulu, dan begitu seterusnya.

\section{Selasa (Mapag Buana)}

Guru dan siswa laki-laki mengenakan kampret putih, sedangkan perempuan mengenakan kebaya putih. Kampret dan kebaya diharapkan dapat diterima sebagai pakaian internasional ciri khas orang Sunda yang akan mendunia. Guru semua mata pelajaran menerangkan materi dan bahan ajar dihubungkan dengan semangat globalisasi. Contohnya:

a. Guru bahasa Inggris menerangkan materi ajar percakapan ringan bahasa Inggris yang mudah dipahami siswa.

b. Guru bahasa Indonesia menerangkan materi ajar tentang betapa pentingnya mengenalkan bahasa Indonesia kepada dunia, dengan harapan bahasa Indonesia kelak dapat menjadi bahasa pengantar dunia.

c. Guru PAI menerangkan semangat perdamaian dunia.

d. Guru Penjaskes menerangkan dan mempraktekkan olahraga yang sudah mendunia.

Pada akhir pelajaran sebelum pulang, guru memberi pertanyaan yang mendunia, contohnya:

"Siapakah Kanselir Jerman yang sekarang? 
"Siswa yang unjuk tangan paling dahulu berhak menjawab, dan jika jawabannya benar maka dia boleh ke luar kelas paling dahulu, dan begitu seterusnya.

\section{Rabu (Maneuh di Sunda)}

Pada hari Rabu, guru dan siswa laki-laki mengenakan kampret hitam, sedangkan perempuan mengenakan kebaya hitam. Kampret hitam dan kebaya hitam pada hari Rabu sebagai wujud orang Sunda yang tidak segan bermandi keringat atau bergumul lumpur lambang pekerja keras dalam hidup. Guru semua mata pelajaran menerangkan materi dan bahan ajar dihubungkan dengan semangat kearifan lokal dan keunggulan lokal budaya Sunda. Contohnya:

a. Guru bahasa Sunda menerangkan nilai luhur budaya Sunda dengan filosofi-filosofi yang mudah dipahami oleh siswa.

b. Guru Seni Budaya dan Keterampilan (SBK) menerangkan beragam seni yang menjadi kekayaan orang Sunda.

c. Guru Bimbingan Konseling menerapkan pemahaman ajaran dan tuntunan yang diambil dari nilai luhur kesundaan. Contoh: Leuleus jeujeur liat tali, herang caina beunang laukna, ka hareup ngala sajeujeub ka tukang ngala salengkah, dst.

Sebelum pulang, menyanyikan salah satu tembang Sunda, contohnya: Bubuy Bulan, Karatagan Pablawan, Isola, dsb. Pada akhir pelajaran sebelum pulang, guru memberi pertanyaan seputar kesundaan, contohnya: "Naon harti paribasa cikaracak ninggang batu laun-laun jadi legok?"

"Naon hartina jalma ulah pagiri-giri calik pagirang-girang tampian?"dst.

Siswa yang unjuk tangan paling dahulu berhak menjawab, dan jika jawabannya benar maka dia boleh ke luar kelas paling dahulu, dan begitu seterusnya.

\section{Kamis (Nyanding Wawangi)}

Pada hari ini, guru dan siswa bebas berpakaian rapi dan sopan. Ini mencerminkan kebebasan ber-estetika dalam penampilan. Guru dapat mengenakan jas, berdasi, atau kemeja batik. Guru semua mata pelajaran menerangkan materi dan bahan ajar dihubungkan dengan keindahan. Keindahan di sini cakupannya luas, dapat dipahami sebagai wujud keinginan manusia yang menyukai segala hal yang indah-indah. Contohnya: a. Guru IPA menerangkan materi bunga, kuncup, putik, dan semerbak taman di depan kelas.

b. Guru bahasa Indonesia menerangkan keindahan sastra. 
c. Guru PAI menerangkan bahwa Allah swt menyukai keindahan.

d. Guru IPS menerangkan betapa indahnya alam Nusantara, dst.

Siswa boleh memberi bunga kepada guru atau wali kelas, sebagai simbol keindahan dan kasih sayang.

\section{Jumat (Nyucikeun Diri)}

Guru dan siswa mengenakan pakaian muslim dan muslimat. (kecuali non muslim, berpakaian bebas). Membaca Alquran bersama-sama di dalam kelas. Guru semua mata pelajaran menghubungakan materi dan bahan ajar dengan keagungan Allah swt sebagai kholik dan kesucian diri manusia sebagai mahluk-Nya. Contohnya:

a. Guru bahasa menerangkan bahwa bahasa yang dipakai manusia di dunia sebagai alat komunikasi merupakan karunia Allah swt yang tidak ternilai harganya.

b. Guru Matematika menerangkan bahwa sepandai-pandainya manusia dalam berhitung tidak akan mampu menghitung karunia Allah terhadap umat-Nya. Begitu seterusnya.

\section{Sabtu-Minggu (Betah di Imah)}

Sabtu dan Minggu merupakan hari libur sekolah. Guru tidak memberi pekerjaan rumah (PR) kepada seluruh siswanya. Anak-anak berkumpul dengan keluarga. Orang tua diharapkan memberi waktu luang dari segala aktifitas untuk bercengkerama dengan keluarga, membangun kebersamaan yang dapat dilakukan dengan berbagai cara, misalnya:

a. Melakukan aktivitas keagamaan bersama.

b. Makan bersama.

c. Menonton televisi bersama.

d. Mendampingi anak belajar.

e. Mendongeng.

f. Bermain bersama anak.

g. Belanja bersama.

h. Masak bersama.

i. Momen bebas.

j. Liburan bersama.

Dalam upaya membangun dan mencetak generasi yang berkualitas, selayaknya program ini sesegera mungkin dibuat aturan atau petunjuk pelaksanaan maupun petunjuk teknis yang lebih jelas terutama pada disiplin kegiatan pembelajaran. Disiplin dan sanksi harus benar-benar diterapkan terutama kepada para guru dan peserta didik di semua jenjang 
persekolahan. Di samping itu, sosialisasi dan pelatihan-pelatihan tentang tujuh poe atikan harus rutin dilakukan untuk membentuk karakter yang baik bagi para pendidik. Ketika karakter dari para ujung tombak pendidikan ini sudah berkualitas, maka hasil yang didapatkan dari proses pendidikan adalah anak-anak dengan pola pikir serta perbuatan yang berkarakter.

\section{SIMPULAN DAN REKOMENDASI}

Program tujuh poe atikan pada tingkatan institusi mengarah pada pembentukan budaya sekolah, yaitu nilai-nilai yang melandasi perilaku, tradisi, kebiasaan keseharian, dan simbol-simbol yang dipraktikkan oleh semua warga sekolah, dan masyarakat sekitar sekolah. Budaya sekolah merupakan ciri khas, karakter atau watak, dan citra sekolah tersebut di mata masyarakat luas.

Melalui program ini, lulusan sekolah di Kabupaten Purwakarta, memiliki keimanan dan ketaqwaan kepada Tuhan Yang Maha Esa, berakhlak mulia, berkarakter mulia, kompetensi akademik yang utuh dan terpadu, sekaligus memiliki kepribadian yang baik sesuai norma-norma dan budaya Indonesia. Pada tataran yang lebih luas, program tujub poe atikan nantinya diharapkan menjadi budaya sekolah.

\section{REFERENSI}

Alwi, Hasan. (2005). Kamus Besar Bahasa Indonesia. Jakarta: Balai Pustaka.

Desmita. (2011). Psikologi Perkembangan Peserta Didik. Bandung: Remaja Rosda Karya.

Isna, Nuria. (2011). Panduan Menerapkan Pendidikan Karakter di Sekolah. Jogjakarta: Laksana.

Istiqomah. (2014). Pola Asuh Otoriter Orang Tua, Kecerdasan Emosi, dan

Kemandirian Anak SD. Jumal Psikologi Indonesia.Vol.3, No.01, hal1-8.

Gunarsa, Singgih. 2008. "Psikologi Perkembangan Anak dan Remaja”.BPK Gunung Mulia.

Peraturan Bupati. (2015). Pendidikan Berkarakter No. 69 Pasal 5 ayat 2.

Kasupardi, Endang. (2017). Cing Caringcing Pageuh Kancing Set saringset Pgeuh Iket. Purwakarta: Pemda Purwakarta.

Kemdiknas. (2010). Buku Induk Pembangunan Karakter. Jakarta: Kemendiknas.

Mulyadi, Dedi. (2017). Mengayuh Negeri dengan Cinta. Bandung: Simbiosa Rekatama Media

Spradley, J. (2006). Metode Etnografi. Yogyakarta: Tiara Wacana.

Madrosatuna: Jurnal Pendidikan Guru Madrasah Ibtidaiyah 1(1) (2018) 62-72 
Suharnan. (2012). Pengembangan Skala Kemandirian. Jurnal Psikologi Persona, Volume 1 Nomor 02 September.

Suhendi. (2014). Cara Dahsyat Menulis Artikel. Bekasi: Gramata Publishing. Tim Penyusun. (2005). Kamus Bahasa Sunda. Bandung: Balai Bahasa.

Tim Penyusun. (2008). Kamus Bahasa Indonesia. Jakarta: PT Gramedia Pustaka Utama.

Sari, Winda. (2016). Meningkatkan Kemandirian Anak Di Sentra Bahan Alam pada Tk Bunga Mekar Kecamatan Seulimeum Kabupaten Aceh Besar. Jurnal Ilmiah Mahasiswa Pendidikan Anak Usia Dini, 1(1):108-114.

Walgito. (2010). Pengantar Psikologi Umum. Yogyakarta: Andi.

Wulandari, Hayani. (2016). Menumbuhkan Pendidikan Karakter Melalui Atikan Purwakarta pada Pendidikan Usia Dini. Jurnal UPI Kampus Purvakarta. 